Olga Podlińska

Szkoła Glówna Gospodarstwa Wiejskiego w Warszawie

\title{
Przetwórstwo spożywcze w Polsce na tle krajów Unii Europejskiej
}

\section{FOOD PROCESSING IN POLAND AGAINST THE EUROPEAN UNION COUNTRIES}

\begin{abstract}
Celem artykulu jest ukazanie pozycji polskiego przetwórstwa spożywczego na tle przetwórstwa spożywczego $w$ krajach Unii Europejskiej oraz przedstawienie przetwórstwa spożywczego w Polsce na tle catego przemystu. Realizację podjętej tematyki rozpoczęto od studiów literaturowych pozycji krajowych jak i międzynarodowych. W części empirycznej wykorzystano dane publikowane przez Europejski Urzad Statystyczny EUROSTAT oraz Główny Urzqd Statystyczny GUS. W celu zobrazowania pozycji przetwórstwa spożywczego postużono się udziatem procentowym produkcji sprzedanej przemystu spożywczego w ogólnej wartości produkcji sprzedanej przemystu. Biorac pod uwage udziat catkowitej wartość produkcji sprzedanej $w$ krajach Unii Europejskiej w 2016 r. Polska znalazła się wśród liderów krajów członkowskich, zajmując szósta pozycję. Z udziałem 4\% uplasowała się za Niemcami, Włochami, Francja, Wielkq Brytaniq i Hiszpaniq. Zestawienia w opracowaniu dotyczq lat 2015 i 2016.
\end{abstract}

Słowa kluczowe: przetwórstwo spożywcze, przemysł, przemysł spożywczy

\section{Wstęp}

Przetwórstwo spożywcze w Polsce jest jednym z najważniejszych i najbardziej dynamicznie rozwijających się działów krajowej gospodarki. Jego pozycja, w porównaniu do przedsiębiorstw przemysłu spożywczego w krajach Unii Europejskiej, jest dużo silniejsza niż innych dziedzin gospodarki. Jest to między innymi następstwem wieloletnich przemian strukturalnych i systemowych, które miały miejsce po 1989 roku, skutkujących uzyskaniem poziomu nowoczesności zbliżonego do największych potęg na tym rynku, tj. Francji, Niemiec, Włoch, Wielkiej Brytanii i Hiszpanii ${ }^{1}$. Zmiany te były wymuszane również przez rynek i konkurencję wewnętrzną związaną z dostosowaniem naszego przemysłu spożywczego do funkcjonowania na rynku unijnym. Dotyczyły one wszystkich branż, choć zmiany te w poszczególnych branżach miały inny charakter². Procesy integracji europejskiej wpłynęły na przetwórstwo spożywcze poprzez szczegółowe regulacje dotyczące jakości żywności oraz warunków jej produkcji i obrotu jak również przez stosowanie szerokiego zakresu bezpośredniej lub pośredniej

\footnotetext{
${ }^{1}$ A. Kowalski: Polski przemysł spożywczy po integracji. Biuletyn informacyjny MRi RW Nr 3/2005 (94), Warszawa 2005, s.7.

${ }^{2}$ G. Rybicki: Przemiany w przemyśle spożywczym na przykładzie branży mleczarskiej. Roczniki Naukowe SERiA, tom VIII, z. 2, Warszawa 2006, s.182.
} 
interwencji na rynku rolno-żywnościowym oraz stosowanie administracyjnych procedur, ograniczających rynkowe mechanizmy regulacji ${ }^{3}$. Producenci żywności zmuszeni zostali także do stosowania unijnego prawa ochrony konsumenta i konkurencji, ochrony środowiska, regulacji dotyczących pomocy publicznej itd. Wraz z przystapieniem Polski do Unii Europejskiej zaczęło obowiązywać prawo wspólnotowe, dyrektywy i rozporządzenia, a zniesiono obligatoryjność stosowania polskich norm m.in. branżowych ${ }^{4}$.

\section{Cele i metody badawcze}

Celem artykułu jest ukazanie pozycji polskiego przetwórstwa spożywczego na tle przetwórstwa spożywczego $\mathrm{w}$ krajach Unii Europejskiej oraz przedstawienie przetwórstwa spożywczego w Polsce na tle całego przemysłu. Do realizacji celu wykorzystano literaturę krajową jak i międzynarodową. W części empirycznej wykorzystano dane Europejskiego Urzędu Statystycznego EUROSTAT oraz Głównego Urzędu Statystycznego GUS. Badania obejmują producentów artykułów spożywczych oraz producentów napojów, w tym napojów alkoholowych oraz producentów wyrobów tytoniowych. Dotyczą zatem Sekcji C Polskiej Klasyfikacji Działalności, działy: 10, 11 i 12. Pozycję przemysłu spożywczego $\mathrm{w}$ gospodarce narodowej można określić za pomocą takich wskaźników jak:

1. Procentowy udział produkcji sprzedanej przemysłu spożywczego w ogólnej wartości produkcji sprzedanej przemysłu.

2. Procentowy udział zatrudnienia $\mathrm{w}$ przemyśle spożywczym w ogólnym zatrudnieniu w przemyśle.

3. Procentowy udział nakładów inwestycyjnych w przemyśle spożywczym w ogólnych nakładach przemysłu ${ }^{5}$.

W opracowaniu wykorzystano procentowy udział produkcji sprzedanej przemysłu spożywczego w ogólnej wartości produkcji sprzedanej przemysłu. Ze względu na brak kompletnych danych dotyczących polskiego przemysłu za rok 2016, dane w opracowaniu dotyczą lat 2015 i 2016. Uwzględniając brak jednoznaczności w definiowaniu pojęć $\mathrm{w}$ literaturze przedmiotu, przetwórstwo spożywcze i przemysł spożywczy stosowano zamiennie.

\section{Przetwórstwo spożywcze w Polsce i krajach Unii Europejskiej}

Przemysł spożywczy jest największym sektorem produkcji w Unii Europejskiej pod względem miejsc pracy i wartości dodanej. Komisja Europejska pracuje nad poprawą konkurencyjności sektora spożywczego i funkcjonowania jednolitego rynku żywności. Dąży też do stworzenia nowych możliwości handlowych dla produktów spożywczych i

\footnotetext{
${ }^{3}$ Przemiany przemysłu spożywczego w latach 1988-2003. Praca zbiorowa pod redakcją naukową R. Urbana, Wydawnictwo IERiGŻ, Warszawa 2004, s. 12.

${ }^{4}$ R. Wierzejska: Bezpieczeństwo żywności w Polsce w okresie członkostwa w Unii Europejskiej. Przemysł spożywczy, Tom 69, nr 2, Wydawnictwo SIGMA-NOT, Warszawa 2015, s.2.

${ }^{5}$ F. Kapusta: Przemysł spożywczy w Polsce i jego baza surowcowa. Ekonomia XXI wieku nr 2 (6), Wydawnictwo Uniwersytetu Ekonomicznego we Wrocławiu, Wrocław 2015, s. 15.
} 
napojów ${ }^{6}$. Znalezienie nowych rynków zbytu powinno być celem priorytetowym dla wszystkich organizacji wspomagających sprzedaż tego typu produktów.

Z wcześniejszych badań dotyczących przemian polskiego przemysłu spożywczego wynika, że przed wstapieniem Polski do Unii Europejskiej wydajność pracy w tym sektorze w Polsce była dwukrotnie niższa od przeciętnego poziomu krajów członkowskich i trzykrotnie niższa od poziomu krajów wyróżniających się najwyższym poziomem rozwoju tego sektora ${ }^{7}$. Gołaś w swoich badaniach zwraca uwagę na poprawę wydajności pracy $\mathrm{w}$ polskim przemyśle spożywczym, jaka nastąpiła $\mathrm{w}$ pierwszych latach naszego członkostwa w Unii Europejskiej. Jej poziom jednak był o około $60 \%$ niższy niż przeciętnie we Wspólnocie ${ }^{8}$. Polskę zaliczyć można do tych państw członkowskich, w których udział produktów przemysłu spożywczego w eksporcie produktów rolno-spożywczych należy do najwyższych. Jest to ok $80 \%$. Potencjał Polski dotyczący m.in. liczby ludności, produktu krajowego brutto czy wartości produkcji sprzedanej przemysłu spożywczego umożliwia zaklasyfikowanie naszego kraju wśród unijnych liderów9.

Pozycja i siła przemysłu spożywczego w gospodarkach krajów Unii Europejskiej jest zróżnicowana. Świadczy o tym wkład tego działu przemysłu do produktu krajowego brutto (PKB) lub relacja wartości produkcji sprzedanej (WPS) przemysłu spożywczego do PKB.

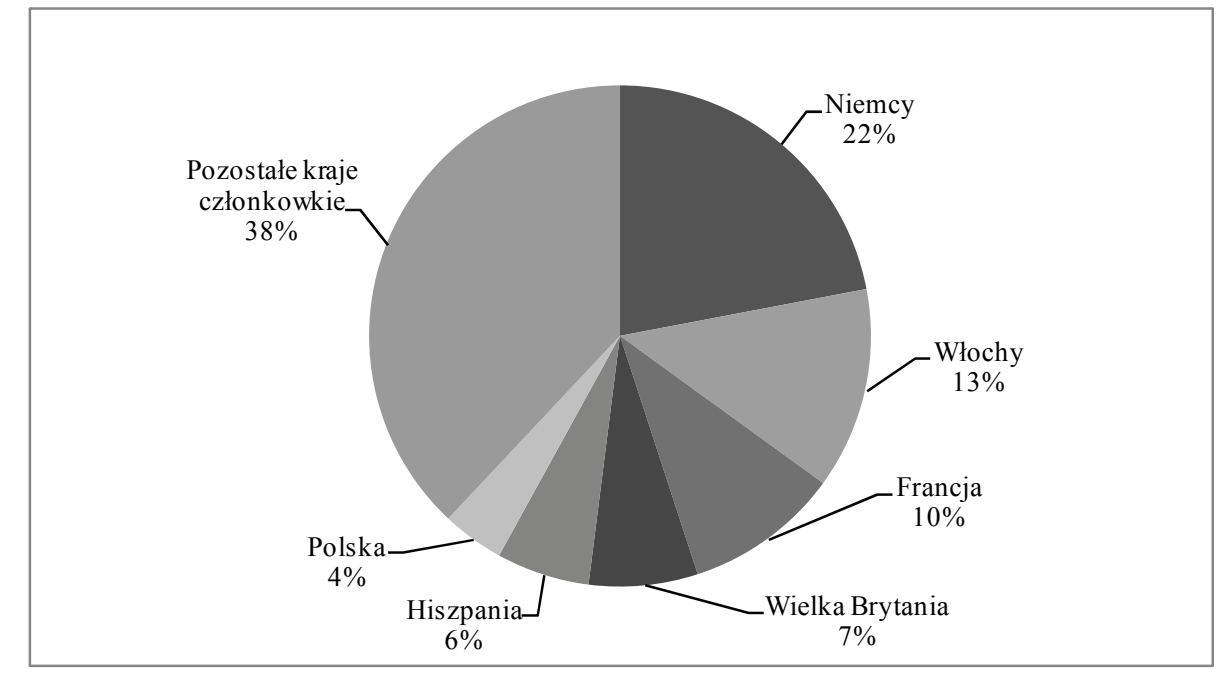

Rysunek 1. Udział całkowitej wartość produkcji sprzedanej przemysłu w krajach Unii Europejskiej w 2016r. Źródło: opracowanie własne na podstawie danych EUROSTAT

\footnotetext{
${ }^{6}$ https://ec.europa.eu

${ }^{7}$ Przemiany przemysłu spożywczego, op.cit., s. 193

${ }^{8}$ Z. Gołaś: Czynniki kształtujące wydajność pracy w przedsiębiorstwach przemysłu spożywczego. Zagadnienia Ekonomiki Rolnej, nr 4, Warszawa 2010, s. 39

9 Przemysł spożywczy- makrootoczenie, inwestycje, ekspansja zagraniczna. Praca zbiorowa pod redakcją naukową I. Szczepaniak, K. Firlej, Wydawnictwo Fundacja Uniwersytetu Ekonomicznego w Krakowie, Kraków 2015, s. 98.
} 
Rysunek 1, dotyczący roku 2016, przedstawia udział poszczególnych państw członkowskich $\mathrm{w}$ całkowitej wartości produkcji sprzedanej przemysłu wytworzonej przez wszystkie kraje unijne. Prawie dwie trzecie wartości produkcji sprzedanej w Unii Europejskiej wygenerowane zostało przez sześć państw członkowskich. Wśród nich Polska z udziałem 4\%, znalazła się na szóstej pozycji za: Niemcami, których udział wynosi 22\%, Włochami, Francją, Wielką Brytanią i Hiszpanią.

Mówiąc o wartości produkcji sprzedanej warto również przyjrzeć się jakie działy produkcji dominują. Zatem rysunek 2 przedstawia wartość produkcji sprzedanej według działalności produkcyjnej dla wszystkich krajów Unii Europejskiej.

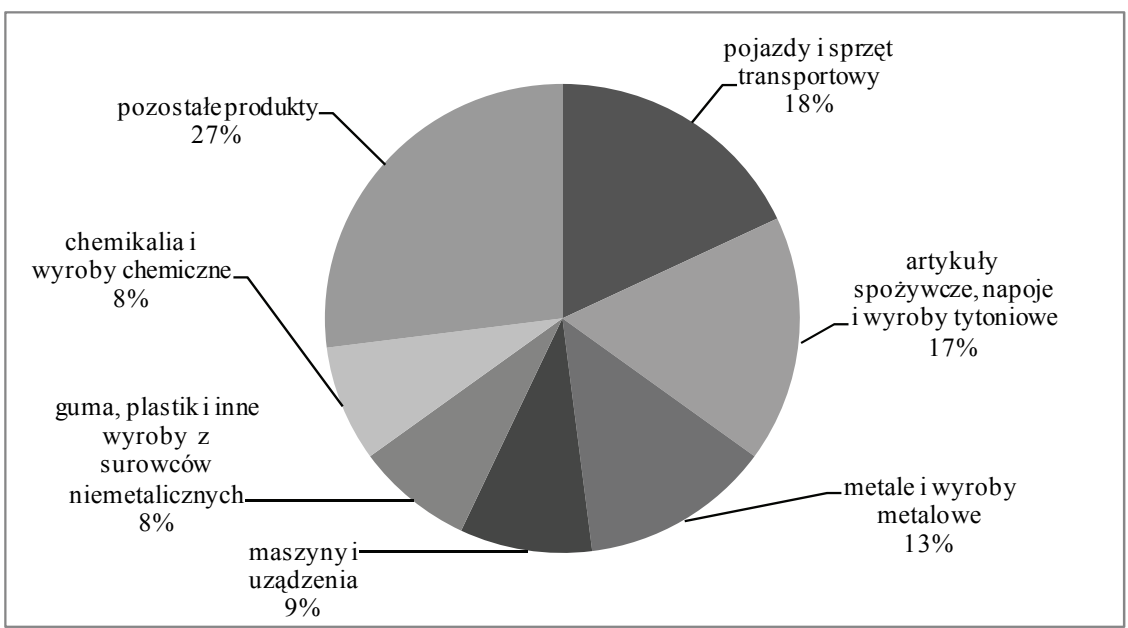

Rysunek 2. Wartość produkcji sprzedanej według działalności produkcyjnej Unii Europejskiej w 2016r. Źródło: opracowanie własne na podstawie danych EUROSTAT

Wartość produkcji sprzedanej we wszystkich krajach Wspólnoty koncentruje się na czternastu grupach działalności. Sześć z tych grup stanowi ponad $70 \%$ całości. Produkcja artykułów spożywczych, napojów i wyrobów tytoniowych, produkcja metali i wyrobów metalowych oraz produkcja pojazdów i sprzętu transportowego stanowiła blisko $50 \%$ wartości produkcji sprzedanej.

Podobny udział poszczególnych działów gospodarki dotyczy też Polski, co przedstawia tabela 1 .

Tabela 1. Udział produkcji sprzedanej wyrobów przemysłowych według działów gospodarki w $2015 \mathrm{r}$.

\begin{tabular}{|c|c|}
\hline Dział gospodarki & $\begin{array}{l}\text { Udział } \\
\text { procentowy }\end{array}$ \\
\hline $\begin{array}{c}\text { artykuły spożywcze, napoje i wyroby } \\
\text { tytoniowe }\end{array}$ & 21,4 \\
\hline drewno i wyroby z drewna i korka & 2,4 \\
\hline papier i wyroby z papieru & 3,5 \\
\hline
\end{tabular}




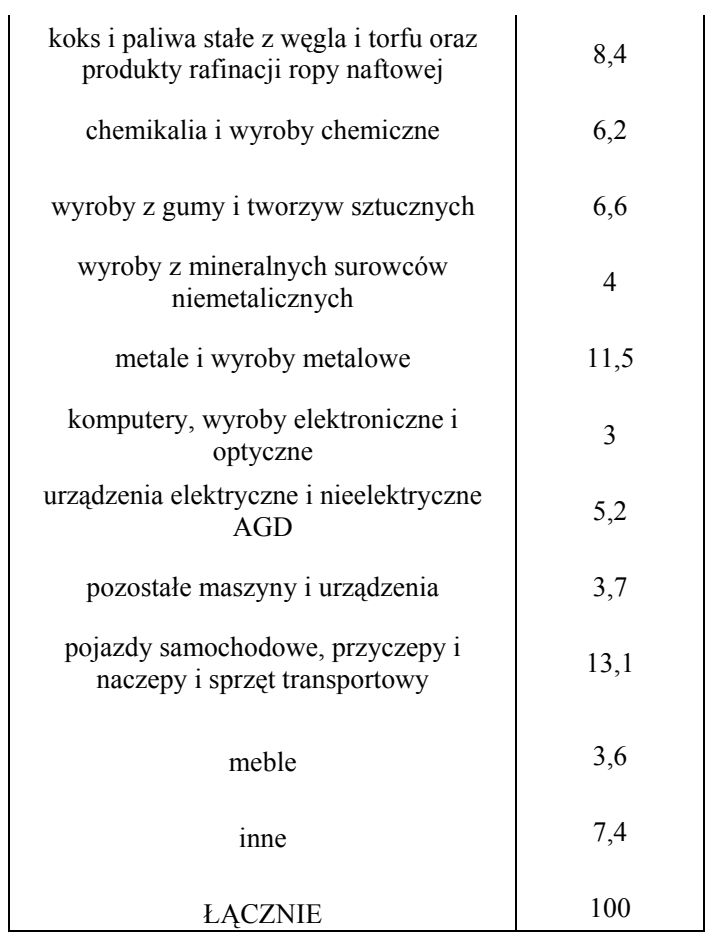

Źródło: opracowanie własne na podstawie danych GUS

W Polsce, podobnie jak w całej Unii Europejskiej, produkcja artykułów spożywczych, napojów i artykułów tytoniowych wyróżniała się największym udziałem w produkcji sprzedanej przemysłu . Kolejne dwa działy to, analogicznie jak w krajach unijnych, wyposażenie transportowe $\mathrm{i}$ wyroby $\mathrm{z}$ metalu. Do kategorii inne zostały zaliczone pozostałe działy gospodarki, których udział produkcji sprzedanej wynosił nie więcej niż $2 \%$. Są to m.in. leki i wyroby farmaceutyczne czy odzież i wyroby tekstylne.

\section{Pozycja przetwórstwa spożywczego w przemyśle}

Przetwórstwo spożywcze obejmuje bardzo szeroki obszar działalności. Funkcjonują w nim firmy zajmujące się zarówno przetwórstwem produktów zwierzęcych jak i roślinnych. Produkty mogą być nisko przetworzone jak i być efektem zaawansowanych procesów technologicznych ${ }^{10}$. Tak rozległy obszar działalności przemysłu spożywczego jako jednego $\mathrm{z}$ działów agrobiznesu, stanowi o wysokim znaczeniu przemysłu spożywczego w gospodarce narodowej ${ }^{11}$. Jest on istotny, o czym świadczy m.in.

\footnotetext{
${ }^{10}$ The competitive position of the European food and drink industry. Final report European Commission, Brussels 2016, s. 31.

${ }^{11}$ P. Beba, W. Poczta: Rozwój i rola polskiego przemysłu spożywczego w warunkach akcesji do Unii Europejskiej. Zeszyty Naukowe Polityki Europejskie, Finanse i Marketing nr 11(60), Wydawnictwo SGGW, Warszawa 2014, s. 11.
} 
stosunek wartości produkcji sprzedanej tego działu przemysłu do wielkości PKB ${ }^{12}$. Potwierdzenie znaczenia przetwórstwa spożywczego w całej gospodarce określono poprzez wskazanie udziału tego działu $\mathrm{w}$ produkcji sprzedanej i wartości dodanej brutto, co przedstawiają rysunki 3 i 4.

Produkt krajowy brutto stanowi końcowy rezultat działalności produkcyjnej jednostek. Zgodnie $\mathrm{z}$ metodyką Głównego Urzędu Statystycznego może być zdefiniowany, zgodnie z podejściem od strony produkcji, jako suma wartości dodanej brutto poszczególnych sektorów instytucjonalnych lub poszczególnych gałęzi. Powiększona jest ona o podatki od produktów pomniejszone o dotacje do produktów. Jest zatem pozycją bilansującą rachunku produkcji gospodarki ogółem ${ }^{13}$. Natomiast wartość dodana brutto stanowi część wytworzonej w przemyśle produkcji globalnej jaka pozostaje po odliczeniu wartości zużycia pośredniego ${ }^{14}$. Podział wartości dodanej brutto całego przemysłu w Polsce w 2015 roku przedstawia poniższy rysunek.

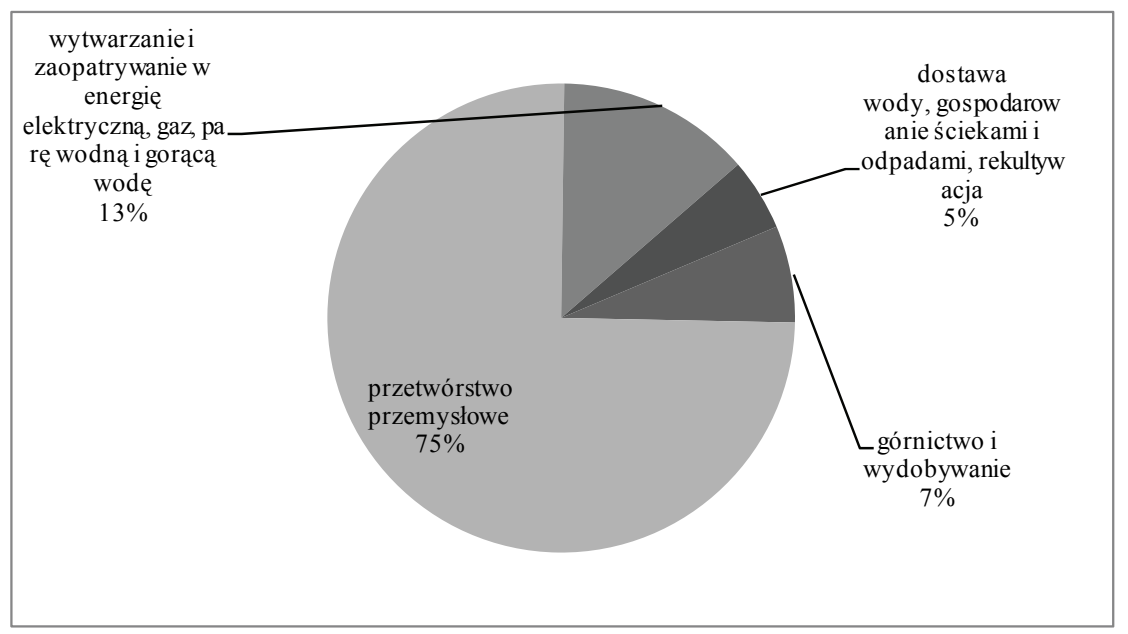

Rysunek 3. Wartość dodana brutto przemysłu w Polsce według sekcji w 2015r.

Źródło: opracowanie własne na podstawie rocznika statystycznego przemysłu 2016

W roku 2015 przetwórstwo przemysłowe stanowiło 75\% wartości dodanej brutto całego przemysłu. Pozostałe trzy działy miały łączny udział na poziomie $25 \%$, przy czym górnictwo i wydobywanie oraz dostawa wody, gospodarowanie ściekami i odpadami i rekultywacja stanowił mniejszy udział łącznie niż wytwarzanie i zaopatrywanie w energię elektryczna, gaz, parę wodną i gorącą wodę. Zainteresowanie budzi udział poszczególnych sekcji należących do przetwórstwa przemysłowego. Rozwinięcie tej części obrazuje rysunek 4.

\footnotetext{
${ }^{12}$ I. Szczepaniak, J. Drożdż, M. Tereszczuk: Zmiany struktury podmiotowej przemysłu spożywczego w Polsce. Przemysł spożywczy, tom 70, nr 6, Wydawnictwo SIGMA-NOT, Warszawa 2016, s. 8.

${ }_{14}^{13}$ www. stat.gov.pl

${ }^{14}$ Rocznik statystyczny przemysłu 2016: Główny Urząd Statystyczny, Zakład Wydawnictw Statystycznych, Warszawa 2016, s. 73.
} 


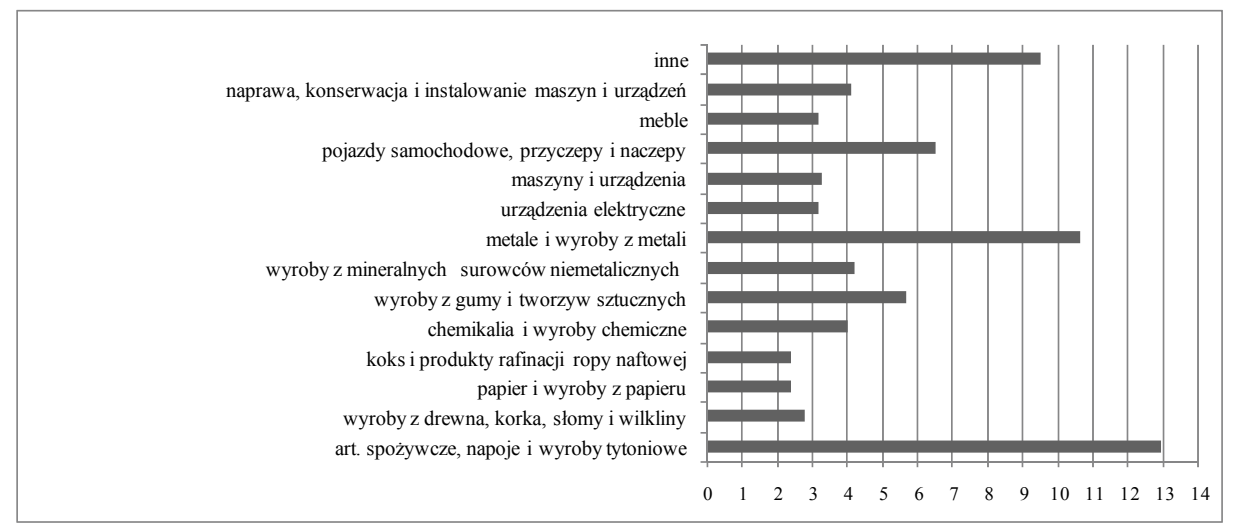

Rysunek 4. Wartość dodana brutto przetwórstwa przemysłowego według sekcji 2015r. (w odsetkach) Źródło: opracowanie własne na podstawie rocznika statystycznego przemysłu 2016

Na podstawie, przedstawionej na wykresie 4, wartości dodanej brutto przetwórstwa przemysłowego w podziale na sekcje zaobserwować można, że produkcja artykułów spożywczych, napojów i wyrobów tytoniowych wyróżnia się największym udziałem w wartości dodanej brutto przetwórstwa przemysłowego w 2015 roku. Wynosi on 12,9\%. W tym produkcja napojów i wyrobów tytoniowych wynosiła odpowiednio $1,5 \%$ i 1,1\%. $\mathrm{Na}$ uwagę zasługuje obok przetwórstwa spożywczego również produkcja metali i wyrobów z metali z udziałem 10,6\% oraz produkcja pojazdów samochodowych, przyczep i naczep, której udział wynosił 6,7\%. Do wspólnej kategorii ,inne”, ze względu na niski udział należą pozostałe sekcje przetwórstwa przemysłowego, których udział stanowi poniżej 2\%. Są to m.in. produkcja komputerów, wyrobów elektronicznych i optycznych, poligrafia i reprodukcja zapisanych nośników informacji czy produkcja wyrobów farmaceutycznych.

\section{Podsumowanie}

Członkostwo Polski w Unii Europejskiej to czas wyróżniający się dużymi zmianami w przetwórstwie spożywczym. Wynika to między innymi z procesu dostosowawczego do wymogów integracji z UE oraz możliwości rozwoju w postaci otwarcia granic na konkurencję międzynarodowa.

Obecnie polski przemysł spożywczy jest liczącym się konkurentem na wspólnym rynku unijnym. Polska jest szóstym producentem żywności w Unii Europejskiej. W roku 2016 udział Polski w całkowitej wartość produkcji sprzedanej w krajach Unii Europejskiej wynosił 4\% . W czołówce znalazły się takie kraje jak Niemcy, Włochy, Francja, Wielka Brytania i Hiszpania. Analizując wartość produkcji sprzedanej Wspólnoty według działalności produkcyjnej największym 18\% udziałem charakteryzowała się produkcja pojazdów i sprzętów transportowych. Drugim działem było przetwórstwo spożywcze z $17 \%$ udziałem. Podobna sytuacja miała miejsce w Polsce w 2015 roku, gdzie udział produkcji sprzedanej wyrobów przemysłowych należących do produkcji artykułów spożywczych, napojów i wyrobów tytoniowych był największy i wynosił 21,4\%. Kolejno drugie i trzecie miejsce zajmowała produkcja 
pojazdów i sprzętu transportowego oraz produkcja metali i wyrobów z metali. W odniesieniu do wartości dodanej brutto przetwórstwa przemysłowego zaobserwowano podobną kolejność wśród dominujących działów gospodarki. Przy czym drugą pozycję zajęła produkcja metali i wyrobów $\mathrm{z}$ metali, a trzecią produkcja pojazdów samochodowych i sprzętu transportowego. Przetwórstwo spożywcze wyróżniało się największym udziałem w wartości dodanej brutto przetwórstwa przemysłowego w 2015 roku.

\section{Bibliografia}

Beba P., Poczta W.: Rozwój i rola polskiego przemysłu spożywczego w warunkach akcesji do Unii Europejskiej, Zeszyty Naukowe Polityki Europejskie, Finanse i Marketing nr 11(60), Wydawnictwo SGGW, Warszawa 2014

Gołaś Z.: Czynniki kształtujące wydajność pracy w przedsiębiorstwach przemysłu spożywczego, Zagadnienia Ekonomiki Rolnej nr 4, IERiGŻ-PIB, Warszawa 2010

https://ec.europa.eu

Kapusta F.: Przemysł spożywczy w Polsce i jego baza surowcowa, Ekonomia XXI wieku nr 2 (6), Wydawnictwo Uniwersytetu Ekonomicznego we Wrocławiu, Wrocław 2015

Kowalski A.: Polski przemysł spożywczy po integracji, Biuletyn informacyjny MRi RW Nr 3/2005 (94), Warszawa 2005

Przemiany przemysłu spożywczego w latach 1988-2003, Praca zbiorowa pod redakcją naukową R.Urbana, Wydawnictwo IERiGŻ, Warszawa 2004

Przemysł spożywczy- makrootoczenie, inwestycje, ekspansja zagraniczna, Praca zbiorowa pod redakcją naukową I. Szczepaniak, K. Firlej, Wydawnictwo Fundacja Uniwersytetu Ekonomicznego w Krakowie, Kraków 2015

Rocznik statystyczny przemysłu 2016: Główny Urząd Statystyczny, Zakład Wydawnictw Statystycznych, Warszawa 2016

Rybicki G.: Przemiany w przemyśle spożywczym na przykładzie branży mleczarskiej, Roczniki Naukowe SERiA tom VIII, z. 2, Warszawa 2006

Szczepaniak I., Drożdż J., Tereszczuk M.: Zmiany struktury podmiotowej przemysłu spożywczego w Polsce, Przemysł spożywczy tom 70, nr 6, Wydawnictwo SIGMA-NOT, Warszawa 2016

The competitive position of the European food and drink industry, Final report European Commission, Brussels 2016

Wierzejska R.: Bezpieczeństwo żywności w Polsce w okresie członkostwa w Unii Europejskiej, Przemysł spożywczy tom 69, nr 2, Wydawnictwo SIGMA-NOT, Warszawa 2015 www. stat.gov.pl

\section{Summary}

The aim of the article is to present the position of the Polish food processing sector in the context of food processing in the European Union countries and to present the food processing in Poland against the whole industry production. The execution of the subject in question started with the literature studies of national and international positions. In the empirical part the data published by the European Statistical Office EUROSTAT and the Central Statistical Office of Poland (GUS) were used. The share of the sold food industry production in the total value of the sold industrial production was used to illustrate the position of the food processing sector. Taking into account the total value of sold production in the European Union countries in 2016, Poland was among the leaders of the member states, occupying the sixth position. With the share of $4 \%$ it was placed after Germany, Italy, France, Great Britain and Spain. The comparisons are for the years 2015 and 2016.

Key words: food processing, industry, food industry 
Informacje o autorze:

\section{mgr Olga Podlińska}

Szkoła Główna Gospodarstwa Wiejskiego w Warszawie

Wydział Nauk Ekonomicznych

Katedra Polityki Europejskiej i Marketingu

e-mail: olgapodlinska@gmail.com 